\title{
The process of marketing management - between the management marketing activities and the operational marketing
}

\author{
Zait Luminita, University Vasile Alecsandri din Bacău
}

\begin{abstract}
Summary:
The best known definitions provided to the concept of marketing management, in the last decades of the 21st century have in common - the orientation towards the client and the development of successfull relations with the clients, the substantion and operationalization of the mix of marketing, as the basis of the exchange relation, the involvement of all functional areas inside the organisation in managing relations in order to achieve the long term objectives of the organization - but the main issues are related to four basic activities: - analysis, planning, implementing and controlling marketing activities.
\end{abstract}

\section{Key words:}

marketing management, analysis, planning, implementing, controlling.

\section{The relation between the levels of organizational structures and the activities of the marketing management process}

The article has the purpose of identifying the way in which the marketing management, as defined in specialized literature, is a process related to the management of all marketing activities or is related to the operational research in the functional level of the organization.

At this point of the analysis, the starting point describing the levels that define the organizational structure of modern companies, in order to emphasize their level, in a logical sequence, the four activities of the marketing management process.

Deshpande and Webster are the first authors that present an organizational structure, in four levels, with the purpose of operationalize the concept of marketing management, namely: corporate level, the division, business unit level and product level. According to these authors:

1. corporate level - the headquarters of the organization - has the purpose of creating a strategic plan to guide all the activities of the organization; it shall take decisions on the amount of resources that are to be allocated to each division, and plan of action (business that are to be developed or removed from the portfolio).

2. in turn, each division establishes a plan related to capital allocation for each business unit in its structure;

3. further on, each business unit develops a strategic plan to generate profitable results 4. Finally, each product level (product line, brand) develops a marketing plan to achieve the objectives.

Despite the innovative theory offered by Deshpande and Webster, there are others views of the specialists, regarding the number of levels, most of them specifying a succesion of three levels (Jain S., 2000; Valerică Olteanu, 2003; David Aaker, 2007; Lambin, 2007): 
1. corporate level, known as corporate marketing, whose role is to provide information regarding the consumer and competition in the strategic planning for the management.

2. the strategic unit called strategic marketing, where marketing is to assist the development perspective of the business unit

3. functional level, called operational marketing, where marketing comes to create and implement marketing programs. It should be noted that there are theories that claim that this functional level is called marketing management and is composed of the size of the whole approach of marketing action.

\section{The process of marketing management - structure and activities}

Specialized national and international literature offers a wide range of models that captures the components of the marketing management process on the three levels of organizational structure.

Thus, the first structure of the marketing management process, provided by Lamb, Hair and McDaniel in his "Essentials of Marketing", presents the following sequence of phases 1.understanding the mission of the organization and the importance of marketing in fulfilling the mission; 2. establishing the marketing objectives; 3.collecting, analysing and processing information regarding the situation of the organization, reflected in the light of strengths and weaknesses, environmental opportunities and threats; 4. developing a marketing strategy - establishing precisely target segments and their specific needs that the organization will try to meet (the target market strategy) and develop optimal marketing activities (marketing mix) in fulfilling the selected target markets. The author considers that marketing mix should combine strategies regarding the product, distribution, promotion and price, in a manner that generates exchanges that satisfy individual and organizational objectives; 5.marketing strategy implementation; 6. quantification of preformances; 7. periodic assessment of marketing efforts, and making changes if necessary.

In a brief analysis of the process proposed by Lamb, Hair and McDaniel we can locate the four activities of marketing management and the three levels of the organizational structure according to table no. 1.1

Table no. 1.1. Locating business management components of the marketing concept and the levels of organizational structure in marketing management process defined by Lamb, Hair and McDaniel

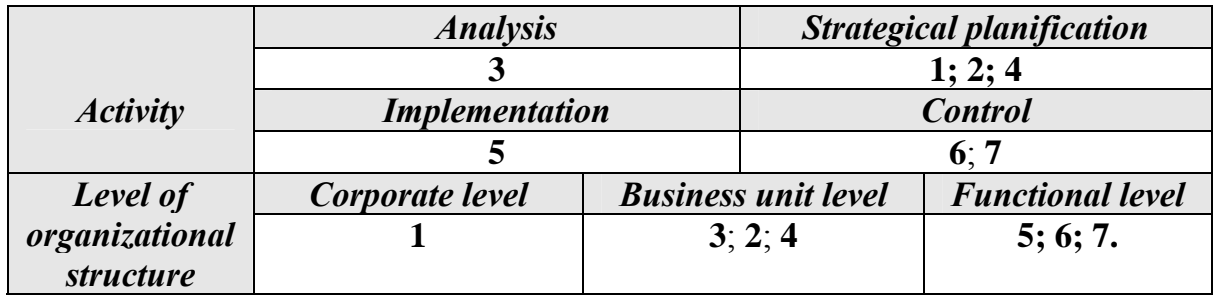

A more simplified structure of the marketing management process is offered by Wright in his work ,Marketing: Origins, Concepts, Environment'”. According to this author, marketing management process is reduced to the three phases with the related activities: 1.marketing planning (a set of objectives, evaluating opportunities, creating marketing strategies, developing marketing plans); 2. implementing marketing plans and programs; 3. controlling plans and marketing programs (measuring results, evaluating progress). 
In a brief analysis of the process proposed by Wright we can locate the four activities of marketing management approach and the three levels of the organizational structure according to table no. 1.2

Table no. 1.2. Locating business management components of the marketing concept and levels of organizational structure in marketing management process defined by Wright.

\begin{tabular}{|c|c|c|c|}
\hline \multirow{4}{*}{ Activity } & Analysis & \multicolumn{2}{|c|}{ Strategical planification } \\
\hline & 1 & \multicolumn{2}{|c|}{1} \\
\hline & Implementation & \multicolumn{2}{|c|}{ Control } \\
\hline & 2 & \multicolumn{2}{|c|}{3} \\
\hline \multirow{2}{*}{$\begin{array}{c}\text { Level of } \\
\text { organizational } \\
\text { structure }\end{array}$} & Corporate level & $\begin{array}{c}\text { Business unit } \\
\text { level }\end{array}$ & Functional level \\
\hline & $\begin{array}{l}\text { It has been not } \\
\text { mentioned specific } \\
\text { elements of this level }\end{array}$ & 1 & $2 ; 3$ \\
\hline
\end{tabular}

John Mullins and Orville Walker, in the "Marketing Management: A Strategic, Decision-Making Approach" propose a more detailed structure, focusing on specific elements of strategic planning, as premises of a rigorous leadership marketing activities, such: 1. external environment analysis aimed at: a. the role of marketing in developing strategies (goals and strategies related to corporate level and strategic units); b. analysis of market opportunities (the 4C - company, context, customer, competitors) emphasizing issues such as understanding market opportunities, consumer behavior, marketing research, marketing segmentation and target selection target, positioning; 2. development of strategic marketing programs (the 4P product, price, placement, promotion), including decisions related to marketing programs and business strategies and decisions related to the 4P; 3. developing strategic marketing programs for selected situations (related strategies in new markets, the growing markets, maturity and decline); 4. implementation and management of marketing programs emphasising on the organizing and planning of the implementation and performance measuring and motivating marketing performances.

Mullins and Walker are the authors that mention the importance of modern informational marketing systems inside an organization, and liable research, in order to support the process of marketing management. Under the proposed structure of the two authors, the whole process of management of marketing activity can be reduced to the blending of the three stages (but that includes the majority of specific strategic planning found in the other theories) such as: strategic plan (mission, goals, strategies, portfolio of activities) marketing plan (environmental analysis, marketing objectives, target market selection, marketing mix), implementing and monitoring strategic plans and marketing.

In a brief analysis of the process proposed by John Mullins and Orville Walker we can locate the four activities of marketing management approach and the three levels of the organizational structure according to table no. 1.3

Table no.1.3. Locating business management components of the marketing management concept and levels of organizational structure in marketing management process defined by John Mullins and Orville Walker

\begin{tabular}{l|l} 
Analysis & Strategical planification
\end{tabular}




\begin{tabular}{|c|c|c|c|}
\hline \multirow{2}{*}{ Activity } & \multicolumn{2}{|c|}{$1 . \mathrm{b}$} & \multicolumn{2}{c|}{ 1.a.; 2; 3 } \\
\cline { 2 - 4 } & \multicolumn{2}{|c|}{ Implementation } & \multicolumn{2}{c|}{} \\
\cline { 2 - 4 } & \multicolumn{2}{|c|}{4} & \multicolumn{2}{c|}{$\begin{array}{c}\text { Functional level } \\
\text { Level of } \\
\text { organizational } \\
\text { structure }\end{array}$} & Corporate level & \begin{tabular}{c} 
Bunit \\
\cline { 2 - 4 }
\end{tabular} & $1 . \mathrm{a}$ & $1 . \mathrm{a} ; 1 . \mathrm{b} ; 2 ; 3$ & 4 \\
\hline
\end{tabular}

Philip Kotler in his work "Marketing Management: Analysis, Planning, Implementation and Control", provides a structure of the management process starting from the definition of marketing activity in an organization according to which: "marketing activity is to analyze market opportunities that arise, studying and choosing target markets, developing marketing strategies, marketing programs, organization, implementation and control of marketing efforts".

Thus, the stages of marketing management According to Kotler's are: 1. analysis of market opportunities, 2. study and the choice of target markets; 3. developing marketing strategies; 4. developing marketing programs and 5. organization, implementation and control of marketing effort.

In a brief analysis of the process proposed by Kotler we can locate the four activities of marketing management approach and the three levels of the organizational structure according to table no. 1.4.

Table no.1.4. Locating business management components of the marketing management concept and levels of organizational structure in marketing management process defined by Kotler

\begin{tabular}{|c|c|c|c|}
\hline \multirow{4}{*}{ Activity } & \multicolumn{2}{|c|}{ Analysis } & Strategical planification \\
\hline & \multicolumn{2}{|c|}{$1 ; 2$} & $3 ; 4$ \\
\hline & \multicolumn{2}{|c|}{ Implementation } & Control \\
\hline & \multicolumn{2}{|c|}{5.} & 5. \\
\hline \multirow[b]{2}{*}{$\begin{array}{l}\text { Level of } \\
\text { organizational } \\
\text { structure }\end{array}$} & Corporate level & Business unit level & Functional level \\
\hline & $\begin{array}{l}\text { It has been not } \\
\text { mentioned } \\
\text { specific elements } \\
\text { of this level }\end{array}$ & $1 ; 2 ; 3 ; 4$ & 5 \\
\hline
\end{tabular}

Structures of the marketing management process similar to those presented up to this point, are provided and Aaker (2007) and Richard Wilson and Colin (2005).

As can be seen from the analysis presented above, most marketing experts place the marketing process management across the three levels of organizational structure, capturing, wider or narrower, the four basic activities - analysis, planning, implementation and control - or their component activities.

A structure of the marketing management process, different from those presented so far is the one proposed by SC Jain in the work, "Marketing, planning and strategy", where the theory proposed highlights the idea that marketing management is reduced to tactic activities that is specific for the functional level.

Basically, for the definition of the concept and development of the marketing management process, the author suggests, as a starting point, the approach to strategic planning. Jain's theory is based on the following statement - to understand the concept of marketing management one must understand the strategic marketing approach.

According to this theory, the corporate level, the essential elements in formulating an overall strategic plan are provided by the marketing imputs: competitive analysis, 
market dynamics and external environmental factors. At this point, marketing represents the bridge between the organization and the reference market, current and future information regarding the area of manifestation of the demand, all of these playing an important role in any strategic planning exercise.

At the other end of the scale is found, according to the author, the marketing management which, by formulating and implementing marketing programs, supports the idea of strategic marketing, on marketing strategies for the various pairs productmarkets.

Marketing strategies are developed at the second level of the structure of the organization, namely the strategic units. In a given context, the marketing strategy is built, essentially, by the interposition of three known forces in literature as the $3 \mathrm{C}$ : consumer, competition and corporate. Marketing strategies are focused on the identification of specific differentiation elements of the competition through capitalization and improvement in order to provide a superior value to customers. According to the theory proposed by Jain between strategic marketing and marketing there are some differences: orientation, philosophy, approach, relationship with environment and other components of the organization, management style needed.

But a few questions of particular interest in terms of analyzing the differences, as follows:

- according to the author, strategic marketing focuses on choosing the right product for the right markets (growing markets), at the right time. Many authors consider, however, that these decisions are not different from those which fall under the area of marketing management.

- according to the author, in marketing management the market segments are defined by grouping customers according to the marketing mix variables, while the strategic marketing approach to market segments is formed to identify the group or groups that can provide more economic benefits for the company then those of the competition. To clarify this issue, Henderson presents the last manner of grouping as being a strategic sector "A strategic sector is where you can gain a competitive advantage and you can exploit it ... Strategic sectors are the key because the reference of any sector is competition'”.

- another difference between strategic marketing and marketing management, mentioned by the author, is that the management of marketing resources and objectives of an organization, howsoever defined, are regarded as being uncontrollable variables in the development of the marketing mix. He considers that in the strategic marketing, objectives are sistematically defined, at the different levels of the organization, following a detailed analysis of the imputs. On the other hand, resources are allocated to maximize corporate performance while the results of the strategy are made more broadly. These issues were mentioned by Abbell and Hammond "The strategic plan of the market is not like ... a marketing plan, is an outline of all aspects of an organization's marketing strategy. Moreover, a marketing plan involves the target segments, product policy, communication, distribution and price to meet and satisfy those segments - so-called marketing mix segments".

- Marketing Management considers that the market projections and the position of competitors as being given and seeks to optimize the activity based on this information. On the other hand, marketing strategy seeks to eliminate these threats.

Despite the arguments offered by Jain and the supporters of his theory, most of the literature converge to the concept and structure of marketing management process as described by Kotler, a marketing management activity (or the application of marketing philosophy) and not as a set of activities confined to the tactical marketing functions. 


\section{Conclusions}

The analysis consists in collecting data and information to ensure the imputs necessary in the knowledge of the external environment (opportunities and threats), of the internal environment (strengths and weaknesses), of the needs manifested in the target markets, of the competitive environment, and of the specific conduct of all stakeholders of activity, from the consumer, dealers and suppliers, competitors to the general public

At this stage, the steps associated to marketing research and marketing and the existence of a viable and operational informational system are extremely important. Only in this way the organization will be able to identify, understand and capitalize all market opportunities

Regarding the approach to strategic planning, the literature, be it marketing or management, is full of works that have attempted to trace the coordinates and its operability. The term strategic planning has been used in marketing literature since the early 60 's, many authors tried to capture its real signification. Thus, according to marketing literature strategic planning can be defined as "a process of creating and shaping the future of the company, a process that consists of senior management efforts to focus on long term business and enterprise performance through a careful formulation, evaluation and substantiation of strategy". The definition offered by Drummond presents an approach to planning at a corporate level, without mentioning the establishment of strategic and marketing strategy.

In view of Malcolm McDonald, strategic planning is” ... the process used to formulate objectives and long-term strategy for the entire company or strategic business unit by linking it with the existing opportunities and resources". The definition formulated by the author, has the merit of pointing out the approach at both corporate and level of the strategic unit, that includes marketing activities. The author states that the strategic planning approach supports organizations in achieving the targets, managing through viable marketing strategy to put themselves in a more advantageous position over its competitors.

For Kenneth J. Cook, strategic planning or the strategic plan represents, "the organization vision regarding its position and its role in the future ... the key to the entire marketing process". Furthermore, the author comes and offers a detailed description of the strategic plan, in two dimensions: as a written definition - a specific vision of the organization to customers, competitors, employees, investors, activities, as a path to the success of the organization, in terms of its role of guidance. Analyzing the last two definitions, we can conclude that the role of the strategic plannification is that of providing the organization a competitive advantage on the market. Starting from this idea, organizations wishing to hold a competitive position must be able to continuously adapt to the environmental changes and apply the principles of market-oriented strategic planning. This concept was supported by Philip Kotler who defined it " ... as a management process for establishing and maintaining a viable relationship between objectives, training employees and resources of an organization on the one hand, and the market situation, on the other hand".

Another author, Manfred Bruhn offers a demarcation between the marketing and management; the author believes that strategic planning is one of the classic functions of management (analysis, planning, implementation and control), while "the process of marketing planning should be seen as an ideal-type approach"'. According to this theory, strategic planning process does nothing but illustrate how the marketing, as a function of the company, assumes a leadership role in the management of the organization to market. Beyond these definitions, strategic planning is a fundamental 
dimension of organizations wishing to position themselves as market-oriented companies, being that component that manages the objectives, capabilities and resources in relation to market opportunities.

In conclusion, marketing planning process is a mental process that decides in advance what, when, why, how and who will be responsible for marketing activities.

Implementation is the key step of the process of marketing management because the operational marketing plan is the basis for achieving the goals of marketing. The plan must be adapted to market conditions and propose a budget for marketing activities. To be effective, a marketing plan must be consistent with the overall strategy of the company, which is why" coordination within the company is essential".

Implementation is, in fact, the one that coordinates all the procedures of a plan. Kotler believes that the implementation of marketing is "the process that turns marketing plans into action plans and provides support for these plans to be executed in such a way as to achieve the objectives of the marketing plan".

Implementation of marketing plans by the marketing manager require the development of certain actions: communication with subordinates to ensure operational action plans, providing guidance and action guides, providing operational resources, surveillance of persons responsible for implementation.

Monitoring and evaluation are activities geared towards the examination of marketing activities in order to identify the efficiency of the marketing plan. The basic aim of these activities is "the verification of financial and marketing objectives". In this respect, the organization must be able to make corrective action if the spread between objectives and results is significant. Moreover, this step is absolutely necessary "the evaluation of marketing strategies of competitors to ensure the permanence of these actions".

Control, according to Kotler's, represents the "examination of the results, financial losses or gains, expenses and marketing opportunities persuasion". Marketing control includes formulation of standard performance, verifying the extent to which the proposed performance is achieved, correcting deviations and marketing plans to reformulate, if necessary.

\section{Bibliography}

1. Aaker, A.D., - Strategic market management, JohnWiley\&SONS, Inc., 2007.

2. Abell, D.F., Hammond, J.S., - Strategic Marketing Planning, Englewood Cliff Prentice Hall, pg.9, 1979

3. Bagozzi, R., - Marketing Management, Prentice Hall, 1998.

4. Bruhn, M. - Orientarea spre clienţi. Temelia afacerii de succes, Editura Economică, Bucureşti, 2002.

5. Deshpande , R., Webster, F.E., - Organizaţional Culture and marketing:defining the research agenda, Journal of Marketing, vol.53, january, pp.3-15, 1989.

6. Drucker, P.F., - Management: Tasks, Responsabilities and Practices, Harper and Row, New York, 1973.

7. Drummond, G. - Strategic Marketing: Planing and Control, 2-nd edition, ButterworthHeinemann, Oxford, 2001.

8. Etzel, M.J., Walker, B.J., Stanton, W.J., - Fundamentals of Marketing, 9th Editon, McgrawHill Book Company, 1999.

9. Henderson, B.D., - Henderson on Corporate Strategy, Harpercollins College Div, pg.4, 1979, 0890115265

10. Jain S.C. - Marketing Planning \& Strategy, Cincinnati, Thomson Learning, 2000.

11. Kenneth, J.Cook - Planificarea strategică pentru întreprinderi mici, Editura Teora, Bucureşti, 1998.

12. Kohli, A.K., Jaworschi, B.J. - Market Orientation: The Construct, Research Proposition and Managerial Implications, Journal of Marketing, vol. 54, issue 2, pp. 1-18, 1990. 
13. Kotler, P., - Marketing Management: Analysis, planning, implementation and control, New Jersy, Prentice Hall Pearson Prentice Hall, 2004.

14. Lamb, Charles W., Hair, Joseph F., McDaniel, C., - Essential of Marketing, SouthWestern Publishing, 2007.

15. McDonald, M., - Marketing strategic, Editura Codecs, Bucureşti, 1998.

16. Mullins, J., Walker, O., - Marketing Management: A Strategic, Decision-Making Approach, 5/e, Mcgraw-Hill, 2005.

17. Richard M. S., Wilson, Colin - Strategic Marketing Management: Planning, Implementation and Control, Elsevier Butterworth-Heinemann Amsterdam, 2005. 